\title{
The Effect of Religiosity and Knowledge Level on Taxpayer Compliance with Awareness of Taxpayers as Intervening Variables (Case Study on Personal Taxpayers at KPP Pratama East Tangerang)
}

\author{
Elok Kurniawati \& Hasian Purba \\ Accounting Study Program, Faculty of Economics and Business, \\ Universitas Mercu Buana \\ Email : elok.kurniawati@mercubuana.ac.id
}

\begin{abstract}
The purpose of this study is as follows: 1) Finding empirical evidence regarding the direct effect of religiosity on taxpayer awareness; 2) Finding empirical evidence regarding the direct influence of the level of knowledge on taxpayer awareness; 3) Finding empirical evidence regarding the direct effect of religiosity on taxpayer compliance; 4) Finding empirical evidence regarding the direct influence of the level of knowledge on taxpayer compliance; and 5) Finding empirical evidence regarding the direct influence of taxpayer awareness on tax compliance.

This type of research is causal. The population in this study is an individual taxpayer in East Tangerang KPP. Sample selection with purposive sampling method. Data collection method used is to use a questionnaire distributed to 100 respondents. The analysis used is path analysis and multiple test.

The results showed, 1) Religiosity directly affects the awareness of taxpayers; 2) The level of knowledge directly affects the awareness of taxpayers; 3) Religiosity directly influences taxpayer compliance; 4) The level of knowledge directly affects the compliance of taxpayers; and 5) Awareness of taxpayers directly affects the compliance of taxpayers.
\end{abstract}

Keywords : Religiosity, Knowledge Level, Taxpayer Awareness, Taxpayer Compliance

DOI: $10.7176 / \mathrm{JCSD} / 52-07$

Publication date:October $31^{\text {st }} 2019$

\section{INTRODUCTION}

Taxes are a source of the National Budget (APBN) which is used to meet the needs of the State. The role of tax is very important to support the smooth running of the economy in the State of Indonesia. Therefore, tax revenues in Indonesia receive a sharp focus by government officials. Various tax regulations were made to support the amount of state revenue. To support the amount of state revenue, taxpayers are required to be obedient in paying and reporting taxes. Obedience of taxpayers in paying and reporting their taxes will increase state revenue, so that the state is not disadvantaged.

The level of taxpayer compliance is influenced by two things namely the internal environment and external environment (Nanik \& Zaenal, 2018). The influence of the internal environment comes from taxpayers themselves, while the external environment comes from outside the taxpayers themselves. This research focuses to discuss internal influences including: religiosity and awareness of taxpayers. Religiosity is the level of one's attachment to the religion of each individual (Nanik \& Zaenal, 2018). All religions in this world provide good guidance for followers of their religion by encouraging good behavior and obeying the prevailing norms.

For someone who has a lot of religious knowledge, belief in his religion, will create someone who is religious. So this person's level of religiosity is trying to behave in accordance with the norms that apply. Likewise, when taxpayers who have high religiosity will try to comply with tax regulations. According to Andhika \& Dudi (2016), and Benk, et al (2016), religiosity affects taxpayer compliance. In contrast to research conducted by Stella (2014) shows that religiosity does not affect taxpayer compliance. This is because taxpayers have different views between religious affairs and business matters.

In addition, public knowledge about taxation must be optimized either through socialization or through character education. Because indirectly, with the knowledge of taxpayers, it is expected that taxpayers will be aware of their obligations in paying taxes because taxes are useful for mutual needs in building a prosperous and prosperous country. Research conducted by Viega \& Fidiana (2017) shows that there is a positive influence of tax knowledge on tax compliance. The same thing was also conveyed in a study conducted by Siti et al, (2017) with the title "Effect of Understanding, Knowledge and Tax Amnesty to pay Tax Compliance with Individual Parliamentary 
Regional in Indonesia". The results of the study explain that tax knowledge has a significant effect on the compliance of individual taxpayers in paying their tax obligations.

Compliance with taxpayers in Indonesia is still low, this is because the Indonesian people are not so aware of the important role of taxes for the welfare of the Indonesian people. Taxpayers in Indonesia assume that tax regulations are increasingly burdensome taxpayers so taxpayers are reluctant to pay taxes. In addition, the low level of compliance of taxpayers in Indonesia is because taxpayers only fulfill tax obligations to avoid tax audits and avoid tax penalties (Wana, et al, 2015). In line with research conducted by Nanik \& Zaenal (2018) shows that the higher the level of awareness possessed by taxpayers, the higher the level of compliance possessed by taxpayers. But in contrast to research conducted by Tahar and Rachman (2014), Nugroho, et al (2016), and Suharyono (2019), which shows that awareness of taxpayers cannot affect taxpayer compliance because taxpayers pay taxes simply because they are afraid to get a penalty fine not because of the awareness of taxpayers.

For reasons like the above, this study intends to examine religiosity, level of knowledge, awareness of taxpayers, and taxpayer compliance on personal taxpayers in East Tangerang KPP with the title: "The Effect of Religiosity and Knowledge Level on Taxpayer Compliance with Awareness of Taxpayers as Intervening Variables (Case Study on Personal Taxpayers at KPP Pratama East Tangerang)".

\section{LITERATURE REVIEW}

Attribution Theory

Relationship theory has been proposed to develop explanations for the ways we value individuals differently, depending on the meaning we associate with certain behaviors. Basically, this theory suggests that when observing an individual's behavior, we try to determine whether the behavior is caused internally or externally. (Robbins, 2008 in Sri, 2018)

Behavior that is caused internally is behavior that is believed to be under the personal control of that individual. Behavior that is caused externally is seen as a result of external causes, that is, the person is seen as forced to behave thus by the situation. (Robbins, 2008 in Sri, 2018).

The reason for choosing this theory is the willingness of taxpayers to pay taxes related to taxpayers in making an assessment of the tax itself. Aiming to make an assessment of someone's perception of something is strongly influenced by internal and external conditions of the person. So the theory of attribution is very relevant to explain this intention.

\section{Social Learning Theory}

Social learning theory states that a person can learn through direct observation and experience (Bandura, 1977 in Ishti, 2013). According to Bandura (1977) in Ishti (2013), the process in social learning includes: 1). Attentional process; 2). Retention process; 3). Motor reproduction process; and 4). Strengthening process

This social learning theory is relevant to explain the behavior of taxpayers in fulfilling their tax obligations. Someone will be obedient to pay taxes on time if through observation and direct experience, the tax money they pay has made a real contribution to the development in their area.

\section{Theory of Reasoned Action}

Theory Reasoned Action was first coined by Ajzen in 1980. This theory was prepared using the basic assumption that humans behave in a conscious manner and consider all available information. According to Fishbein and Ajzen (1975) in Jogiyanto (2015), attitude is the amount of affection (feeling) a person feels to accept or reject an object or behavior and is measured by a procedure that places individuals on a two-pole evaluative scale, for example good or bad, agree or reject and so on. Furthermore, subjective norms are defined as one's perceptions or views of other people's beliefs that will influence the intention to do or not perform the behavior under consideration (Jogiyanto, 2015).

According to Gibbon et al (1998), rational thinking processes mean that in every voluntary behavior there will be a decision making process that is concretely manifested in the intention to carry out a behavior. Further explained by Eagley and Chaiken (1993) that in the framework of a theory of reasoned action, attitudes are transformed indirectly in the form of open behavior through the mediation of psychological processes called intentions. Therefore it can be concluded that intention is a psychological process whose existence lies between attitude and behavior.

Many studies in the social field have proven that Theory of Reason Action (TRA) is a sufficient theory in predicting behavior. However, after a few years, Ajzen conducted a meta-analysis, it was found that a conclusion that Theory 
Reason Action (TRA) only applies to behavior that is under the complete control of the individual because there are factors that can hinder or phallize the relation of intention into behavior. Based on this analysis, Ajzen then added a factor related to individual control, namely perceived behavior control (PBC). Adding one factor then changes the Theory of Reason Action (TRA) to Theory of Planned Behavior (TPB).

\section{Theory of Planned Behavior}

According to Ajzen (2002) "Theory of Planned Behavior (TPB) explains that behavior determined by individuals arises because there is an interest in behavior. There are three behavioral factors that influence the intention to behave. That is : 1) Behavioral beliefs are individual beliefs about the results of a behavior and evaluation of these resultan; 2) Normative beliefs are beliefs about the normative expectations of others and motivation to meet these expectations; and 3) Control beliefs are beliefs about the existence of things that support or hinder the behavior that will be displayed and their perception of how strong the things that support and hinder their behavior (perceived power)".

Bobek \& Hatfield (2003) and Hanno \& Violette (1996), used Theory of Planned Behavior (TPB) to explain tax compliance for individual taxpayers with the finding that attitudes toward tax non-compliance significantly influence the intention of tax non-compliance. So in this study, Theory of Planned of Behavior is relevant to explain the behavior of taxpayers in fulfilling their tax obligations.

\section{Religiosity}

Religiosity is a person's religious attitude to act honestly and act fairly in accordance with their respective beliefs. Religiosity refers to the level of attachment of the individual to the religious values that are adhered to. All religions generally have the same goal in controlling good behavior and inhibiting bad behavior. Religion is expected to provide internal control for self-monitoring in moral behavior. Religious commitment is used as a key variable to measure the level of individual religiosity based on the application of religious values, beliefs and practices in daily life (Stella, 2014).

According to Glock (1962) in Basri (2014) states that religiosity can be divided into five dimensions. First, the ideological dimension, where followers of religion are expected to obey certain rules of belief. Second, the ritualistic dimension, where certain religious practices are followed by followers such as prayer, fasting, and meditation. Third, the dimension of experience that emphasizes religious experience as an indicator of the level of religiosity. Fourth, the intellectual dimension that focuses on religious knowledge used to strengthen one is religious belief. And fifth, the consequential dimension identifies the effect of adherence to the first four individual dimensions.

\section{Taxation Knowledge}

Knowledge is the result of human knowing about something, or all human actions to understand a certain object that can be either tangible goods through reason, can also be understood as an ideal object of human beings, or concerned with psychiatric problems. Taxes are people's contributions to the state treasury based on the law (which can be forced) by not getting lead services that can be directly shown and which are used to pay public expenses (Mardiasmo, 2016). So in conclusion, tax knowledge is the ability of taxpayers to know tax regulations both about tax rates based on the laws they will pay and tax benefits that will be useful for their lives (Utomo, 2011).

Knowledge of tax regulations is very important to foster compliance. Because how can taxpayers obey if they do not know how the tax regulations. With the knowledge of taxpayers about good tax will be able to minimize the existence of tax evation (Witono, 2008 in Nurulita, 2017). With the knowledge of taxation will help taxpayer compliance in paying taxes, so the level of compliance will increase. Taxpayers who are knowledgeable about tax, will self-consciously be obedient to pay taxes. They already know how the flow of tax revenue will run, until finally the benefits of paying the tax are felt. A taxpayer will obey pay taxes if the taxpayer has knowledge of taxation well. If the taxpayer knows the tax regulations, then the taxpayer will obey his tax obligations and will increase taxpayer compliance

\section{Taxpayer Compliance}

According to the Big Indonesian Dictionary, the term obedience means obedience, obedience. Compliance is the motivation of a person, group or organization to act according to established rules (Fajriyan, 2015). In tax, the rule that applies is taxation law. Tax compliance is a person's compliance, in this case is the taxpayer, to tax regulations or laws (Tiraada, 2013). 
Based on the Minister of Finance Regulation No. 74 / PMK.03 / 2012 concerning the procedure for determining taxpayers with certain criteria in the framework of returning the preliminary overpayment of tax payments Chapter II article 2, compliant taxpayers are those who meet four criteria, namely: (1) timely submitting a notice for all types of taxes, (2) have no tax arrears, except tax arrears that have obtained permission to pay in installments or postpone tax payments, (3) financial statements audited by a public accountant or government financial oversight body with a reasonable opinion without exception for 3 (three) years and (4) has never been convicted of a criminal offense in taxation based on a court decision that has had permanent legal force for the past 5 (five) years.

The issue of compliance becomes important because non-compliance together will lead to efforts to avoid taxes which results in reduced depositing of tax funds into the state treasury. So the higher the level of truth counts and calculates. the accuracy of depositing, and filling out and submitting taxpayers' notification, it is expected that the higher level of taxpayer compliance in carrying out and meeting their tax obligations.

\section{Taxpayer Awareness}

Awareness of taxpayers is a logical consequence for taxpayers, namely the willingness of taxpayers to contribute funds to the implementation of the tax function by paying taxes on time and in the right amount.

Based on the Big Indonesian Dictionary, awareness means things that are felt or experienced by someone or knowing, while taxation is about tax. So tax awareness is a willingness to fulfill obligations and contribute to countries that support state development.

\section{Prior Research}

Previous studies that can support this research are as follows: Nugroho et al. (2016) in his study entitled Influence of Taxpayer Awareness and Taxpayer Knowledge of Taxation Against Taxpayer Compliance in Paying Income Taxes (Case Study on KPP Semarang Candi). The results of this study indicate that tax awareness partially does not affect the fulfillment of individual tax obligations. Knowledge of taxation partially affects the fulfillment of tax compliance figures. Tax awareness, and tax knowledge simultaneously influences taxpayer compliance rates. Andhika and Dudi (2016) in their study entitled "The Effect of Religiosity on the Behavior of Personal Taxpayer Compliance in DKI Jakarta Province. The results showed that religiosity had a significant influence on voluntary tax compliance.

Nanik \& Zaenal (2018) in his research entitled "The Effect of Religiosity on Taxpayer Compliance with Taxpayer Awareness as Intervening Variables". The results showed that: 1). Religiosity affects taxpayer compliance, 2). Religiosity affects taxpayer awareness, 3). Awareness of taxpayers affect the compliance of taxpayers, 4). Awareness of taxpayers is able to mediate some of the effects of religiosity on taxpayer compliance.

Beny, et al (2018) in their study entitled "The Effect of Tax Amnesty and Tax Amnesty Knowledge on Tax Compliance Post-Tax Individual Amnesty". Based on the results of research that has been done, it explains that tax knowledge has a significant effect on tax compliance of individual taxpayers after tax amnesty. Tax amnesty significantly influences tax compliance of individual taxpayers after tax amnesty.

Suharyono (2019) conducted a study on the influence of taxpayer awareness and tax knowledge on taxpayer compliance in paying land and building taxes in Bengkalis Regency. This study found that: 1) Awareness of taxpayers does not affect the compliance of taxpayers in paying the Land and Building Tax in Bengkalis Regency; 2) Knowledge of taxation does not affect the compliance of taxpayers in paying Land and Building Tax in Bengkalis Regency; 3) Simultaneously awareness of taxpayers and tax knowledge also does not have a positive effect on taxpayer compliance in paying the Land and Building Tax in Bengkalis Regency.

\section{Research Framework}

Based on the research problem supported by the theoretical foundation and previous research, the research model can be described as follows: 


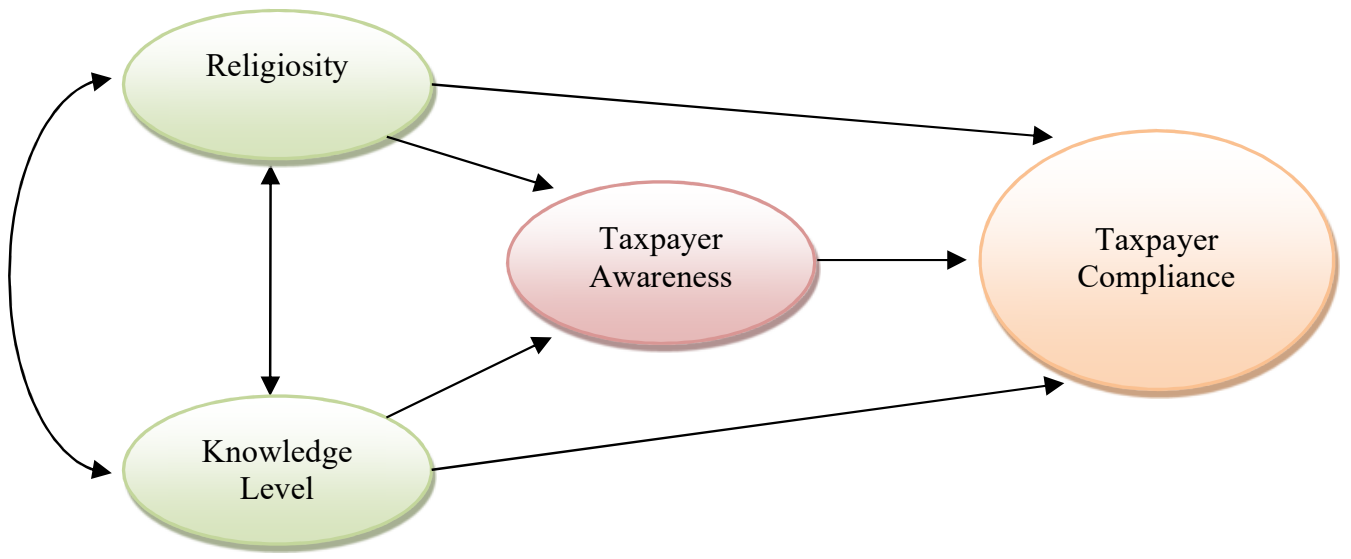

Figure 1.1 Research Model

\section{Hypothesis}

The research hypotheses proposed are as follows:

$\mathrm{Ha}_{1} \quad$ : $\quad$ Religiosity direct effect on Taxpayer Awareness.

$\mathrm{Ha}_{2} \quad: \quad$ Knowledge Level direct effect on Taxpayer Awareness.

$\mathrm{Ha}_{3} \quad$ : $\quad$ Religiosity direct effect on Taxpayer Compliance.

$\mathrm{Ha}_{4} \quad$ : $\quad$ Knowledge Level direct effect on Taxpayer Compliance.

$\mathrm{Ha}_{5} \quad$ : $\quad$ Taxpayer Awareness direct effect on Taxpayer Compliance.

\section{RESEARCH METHODS}

\section{Types of research}

This research is causal which will test the hypothesis about the effect of one or several independent variables on the dependent variable. According to Sarwono and Suhayati (2010) causal research is research conducted to identify causal relationships between variables. Causal research is aimed at finding out which variables function as causes (independent variables) and which variables function as results (dependent variables).

\section{Definition of Variable Operations}

The variables used in this study consisted of one dependent variable, two independent variables and one intervening variable. Operational research variables can be summarized in the following table:

Tabel 1.1 Operationalization of Variables

\begin{tabular}{|c|c|c|c|}
\hline Variables & Concept Variables & Indicator & Scale \\
\hline \multicolumn{4}{|l|}{ Dependent } \\
\hline $\begin{array}{l}\text { Taxpayer } \\
\text { Compliance (Y) }\end{array}$ & $\begin{array}{l}\text { Willingness to report and pay taxes in } \\
\text { accordance with applicable laws }\end{array}$ & $\begin{array}{l}\text { - Compliance with SPT Submission } \\
\text { - Compliant Payment } \\
\text { - Comply with reporting }\end{array}$ & Likert \\
\hline \multicolumn{4}{|l|}{ Independent } \\
\hline Religiosity $\left(\mathrm{X}_{1}\right)$ & $\begin{array}{l}\text { The level of attachment of the } \\
\text { individual to the religious values } \\
\text { adopted. }\end{array}$ & $\begin{array}{l}\text { - The ideological dimension } \\
\text { - The ritualistic dimension } \\
\text { - Dimensions of experience } \\
\text { - Intellectual dimension } \\
\text { - Consequential dimension }\end{array}$ & Likert \\
\hline $\begin{array}{l}\text { Knowledge Level } \\
\left(\mathrm{X}_{2}\right)\end{array}$ & $\begin{array}{l}\text { The process by which taxpayers know } \\
\text { about taxation and apply that } \\
\text { knowledge to pay taxes }\end{array}$ & $\begin{array}{l}\text { - Taxpayer knowledge of the tax function } \\
\text { - Taxpayer knowledge of tax regulations } \\
\text { - Taxpayer knowledge of registration as a } \\
\text { taxpayer } \\
\text { - Taxpayer Knowledge of Tax Payment } \\
\text { Procedures } \\
\text { - Taxpayer knowledge of tax rates }\end{array}$ & Likert \\
\hline \multicolumn{4}{|l|}{ Intervening } \\
\hline $\begin{array}{l}\text { Taxpayer } \\
\text { Awareness }\left(\mathrm{X}_{3}\right)\end{array}$ & $\begin{array}{l}\text { A condition where taxpayers know, } \\
\text { understand and implement tax } \\
\text { provisions correctly and voluntarily. }\end{array}$ & - Awareness of the tax function & Likert \\
\hline
\end{tabular}




\begin{tabular}{|l|l|l|l|}
\hline Variables & Concept Variables & Indicator \\
\hline & & $\begin{array}{l}\text { Scale } \\
\text { coercion } \\
\text { c Awareness of the tax benefits paid } \\
\text { - Awareness that taxes are regulated }\end{array}$ \\
\hline
\end{tabular}

\section{Variable Measurement}

The research instrument was in the form of a questionnaire compiled based on the research indicators of each variable so that there were 4 (three) questionnaires in this study, namely the Religiosity questionnaire, the Knowledge Level questionnaire, the Taxpayer Awareness questionnaire, and the Taxpayer Compliance questionnaire. The questionnaire was compiled using an interval scale using five answer choices as follows:

Strongly Agree (SS)

Agree (S)

Hesitation (R)

Disagree (TS)

Strongly Disagree (STS)
$=$ given a score of 5

$=$ given a score of 4

$=$ given a score of 3

$=$ given a score of 2

$=$ given a score of 1

Population and Research Samples

The population of this study are all Individual Taxpayers who are registered at KPP Pratama East Tangerang. Sampling in this study was conducted using a purposive sampling method. The data obtained by researchers from KPP Pratama East Tangerang, researchers obtained the number of individual taxpayers who do business as much as 7,591 taxpayers. From a population that is clearly known, the calculation of sampling using the Slovin formula is as follows:

$n=\frac{N}{1+N e^{2}}$

$n=\frac{33.439}{1+33.439(10 \%)^{2}}$

$n=\frac{33.439}{335,39}$

$n=99,70$, rounded to 100

Based on these calculations the number of samples in this study were 100 Individual Taxpayers registered at KPP Pratama East Tangerang.

\section{Data collection technique}

The method of data collection in this study was carried out by the sampling method, which is a method of investigation conducted to obtain facts or symptoms that exist and look for facts factually. Data collection was carried out through a questionnaire given to individual taxpayers registered at the KPP Pratama East Tangerang. The questionnaire contains questions that represent each variable in this study.

Data Types and Sources

The type of data in this study are primary data obtained from respondents' responses to the questionnaire sent, while the source of the data comes from individual taxpayer answers that are registered at KPP Pratama East Tangerang.

\section{Analysis Method}

Descriptive statistics

Descriptive statistics in this study are used to provide a description of the character of the research variable using a frequency distribution table that shows the mode number, the range of scores and the standard deviation.

\section{Data Quality Test}

According to Hair et. al (1996, in Sandjojo, 2011), the quality of data generated from the use of research instruments can be evaluated through reliability and validity tests. Each test is to determine the consistency and accuracy of data collected from the use of the instrument.

\section{Test Prerequisite Analysis}

To be able to use path analysis in hypothesis testing, it is necessary to first test statistical prerequisites for the data. The analysis prerequisite tests include tests for normality, homogeneity, and significance and linearity. 


\section{Hypothesis testing}

The design of hypothesis testing used in this study is to use path analysis and Sobel Test. According to Imam Ghozali (2013) to calculate the path coefficient through the following work steps: 1). Draw a path diagram that explains the relationship between variables that reflect the proposed conceptual hypothesis, 2). Calculate the amount of influence (structural parameters) between a cause variable and an effect variable.

The path analysis method used in this study is explained in the figure as follows:

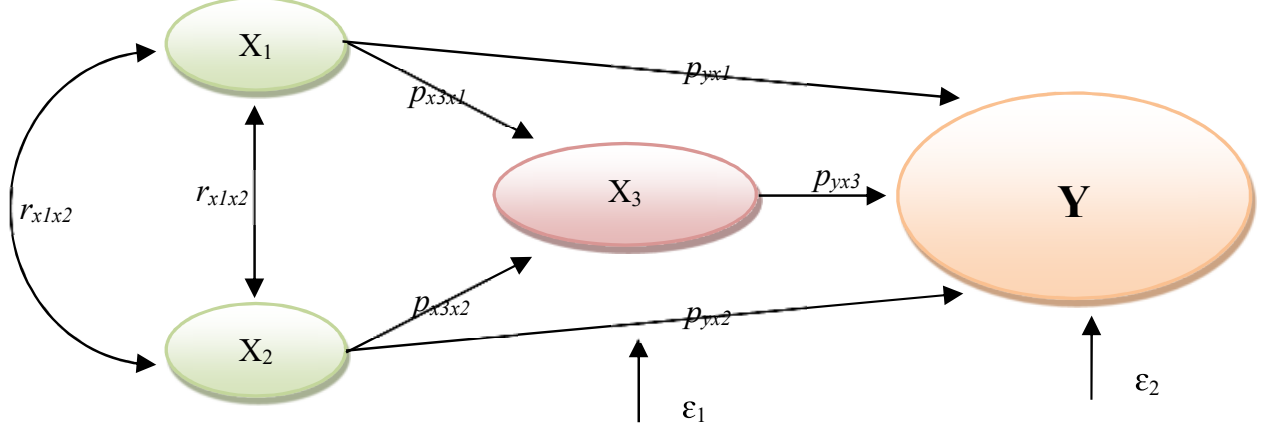

Figure 1.2 Structure of a Path Diagram

Regression models in this study are:

$$
\begin{aligned}
& \mathrm{X}_{3}=\alpha+\rho_{x 3 x 1} \mathrm{X}_{1}+\rho_{x 3 x 2} \mathrm{X}_{2}+\varepsilon_{1} \ldots \ldots \ldots \ldots . . . \ldots \\
& \mathrm{Y}=\alpha+\rho_{y x} \mathrm{X}_{1}+\rho_{y x 2} \mathrm{X}_{2}+\rho_{y x 3} \mathrm{X}_{3}+\varepsilon_{2} \\
& \text { Where } \\
& \mathrm{Y} \quad=\text { Taxpayer Compliance } \\
& \mathrm{X}_{1}=\text { Religiosity } \\
& \mathrm{X}_{2}=\text { Knowledge Level } \\
& \mathrm{X}_{3}=\text { Taxpayer Awareness } \\
& \rho \quad=\text { Path coefficient } \\
& \varepsilon_{1} \quad=\text { Error } \\
& \alpha \quad=\text { Konstanta }
\end{aligned}
$$

In this study, the significance level $(\alpha)$ of 0.05 or $5 \%$ was used. This multiple regression analysis was carried out with the help of the SPSS (Statistical Package For Social Sciences) Release 22.0 for Windows program so that the coefficient of determination, the statistical value of $\mathrm{F}$ and the statistical value of $\mathrm{t}$ were used in hypothesis testing.

\section{Sobel test and Bootstrapping test.}

Sobel test is done by testing the strength of the indirect effect of the independent variable (X) to the dependent variable $(Y)$ through the intervening variable $(\mathrm{Z})$.

An alternative approach to test the significance of mediation using bootstrapping techniques. Bootstrapping is a non-parametric approach that does not assume the shape of the variable distribution and can be applied to a small sample size. Heyes and Preacher (2004) in Ghozali (2013) have developed a sobel and bootstrapping test in the form of SPSS 19 scripts. The hypothesis is that exogenous variables individually influence indirectly on endogenous variables. Basis of Decision Making: 1) If the probability is $t>t$ table then the hypothesis is accepted; and 2) If the probability is tcount $<$ ttable, the hypothesis is rejected. (Ghozali, 2013)

\section{RESEARCH RESULTS AND DISCUSSION}

\section{Research Data Description}

Descriptive analysis is calculated based on the percentage of respondents' answers to research questions using the mean value of each indicator proposed to describe the perceptions of all respondents. Based on the mean (mean), then the respondents' perceptions are interpreted using the three-box method criteria (Ferdinand, 2006), namely: $10.00-40=$ low, $40.01-70=$ moderate, and $70.01-100=$ high. 
Tabel 1.2 Descriptive Statistics Results

\begin{tabular}{|l|c|c|c|c|c|}
\hline \multicolumn{1}{|c|}{ Variabel } & $\begin{array}{c}\text { Nilai } \\
\text { Indeks }\end{array}$ & Minimum & Maksimum & Mean & $\begin{array}{c}\text { Std. } \\
\text { Deviation }\end{array}$ \\
\hline Religiosity & 73,85 & 13 & 30 & 22,16 & 3,894 \\
\hline Knowledge Level & 77,33 & 12 & 25 & 19,33 & 3,362 \\
\hline Taxpayer Awareness & 73,89 & 14 & 30 & 22,17 & 3,950 \\
\hline Taxpayer Compliance & 72,98 & 11 & 25 & 18,24 & 3,292 \\
\hline
\end{tabular}

\section{Source: Primary data processed}

The following are descriptive statistical results about the research variables as follows: The religiosity variable has a minimum value of 13 and a maximum value of 30 . The average religiosity variable is 22.16 with a standard deviation of 3,894 . While the frequency index value of 73.85 . With a frequency index value of 73.85 , it can be concluded that the perception of respondents' answers to the religiosity variable is in the high category, because it is in the range of values between $70.01-100$.

The knowledge level variable has a minimum value of 12 and a maximum value of 25 . The average level of knowledge is 19.33 with a standard deviation of 3.262. While the frequency index value of 77.33 . With a frequency index value of 77.33, it can be concluded that the perception of respondents' answers on the variable level of knowledge in the high category, because it is in the range of values between $70.01-100$.

The taxpayer awareness variable has a minimum value of 14 and a maximum value of 30 . The average taxpayer awareness variable is 22.17 with a standard deviation of 3,950 . While the frequency index value is 73.89 . With a frequency index value of 73.89 , it can be concluded that the perception of respondents' answers to the taxpayer awareness variable in the high category, because it is in the range of values between $70.01-100$.

The taxpayer compliance variable has a minimum value of 11 and a maximum value of 25 . The average taxpayer compliance variable is 18.24 with a standard deviation of 3.292 . While the frequency index value of 72.98 . With a frequency index value of 72.98 , it can be concluded that the perception of respondents' answers to the tax compliance variable in the high category, because it is in the range of values between $70.01-100$.

\section{Data Quality Test}

Validity test

This test is intended to measure the validity of a questionnaire in measuring a contract. And at the same time reinforce the results of previous calculations that all variables measured using the Likert scale can be used for further data processing. Validation Test Results for each variable can be seen in the following table:

Table 1.3 Validity Test Results

\begin{tabular}{|c|c|c|c|}
\hline Variable & $\begin{array}{l}\text { No. } \\
\text { Item }\end{array}$ & Correlation Value & Status \\
\hline \multirow{6}{*}{ Religiosity } & Q1 & 0,768 & Valid \\
\hline & Q2 & 0,713 & Valid \\
\hline & Q3 & 0,777 & Valid \\
\hline & Q4 & 0,723 & Valid \\
\hline & Q5 & 0,589 & Valid \\
\hline & Q6 & 0,427 & Valid \\
\hline \multirow{5}{*}{ Knowledge Level } & Q7 & 0,784 & Valid \\
\hline & Q8 & 0,726 & Valid \\
\hline & Q9 & 0,838 & Valid \\
\hline & Q10 & 0,760 & Valid \\
\hline & Q11 & 0,607 & Valid \\
\hline \multirow{6}{*}{ Taxpayer Awareness } & Q12 & 0,835 & Valid \\
\hline & Q13 & 0,781 & Valid \\
\hline & Q14 & 0,843 & Valid \\
\hline & Q15 & 0,712 & Valid \\
\hline & Q16 & 0,702 & Valid \\
\hline & Q17 & 0,309 & Valid \\
\hline \multirow{5}{*}{ Taxpayer Compliance } & Q18 & 0,434 & Valid \\
\hline & Q19 & 0,784 & Valid \\
\hline & Q20 & 0,838 & Valid \\
\hline & Q21 & 0,696 & Valid \\
\hline & Q22 & 0,708 & Valid \\
\hline
\end{tabular}

Source: Primary data processed 


\section{Reliability Test}

The reliability test is carried out with reference to Cronbach Alpha 0.60. Table 1.4 shows that all instruments of the tested variables have Cronbach alpha above 0.60 , so the test results are quite satisfactory because all instruments have a high level of reliability, so they can be used for further data processing. Reliability Test Results for each variable can be seen in the following table:

Table 1.4 Results of Reliability Testing

\begin{tabular}{|c|l|c|c|}
\hline No & \multicolumn{1}{|c|}{ Variable } & $\begin{array}{c}\text { Cronbach Alpha } \\
\text { coefficient }\end{array}$ & $\begin{array}{c}\text { Number of } \\
\text { Instruments }\end{array}$ \\
\hline 1 & Religiosity & 0,667 & 6 \\
\hline 2 & Knowledge Level & 0,797 & 5 \\
\hline 3 & Taxpayer Awareness & 0,717 & 6 \\
\hline 4 & Taxpayer Compliance & 0,732 & 5 \\
\hline
\end{tabular}

Source: Primary data processed

\section{Test Prerequisite Analysis}

Normality test

Testing for normality using the Lilliefors test. Provisions in the error test are if the statistic L count $<\mathrm{L}$ table $(\alpha=$ $0.05)$, then the error data is normally distributed. But if $\mathrm{L}$ count $>\mathrm{L}$ table $(\alpha=0.05)$, then the data is not normally distributed. Thus the overall results of the normality test calculation using the Lilliefors test can be seen in the summary in table 1.5 .

Table 1.5 Summary of the Normality Test

\begin{tabular}{|c|c|c|c|c|c|c|}
\hline \multirow{2}{*}{ No } & \multirow{2}{*}{ Estimated } & \multirow{2}{*}{$\mathbf{n}$} & \multirow{2}{*}{ L Count } & \multicolumn{2}{|c|}{ L Table } & \multirow{2}{*}{ Decision } \\
\cline { 5 - 6 } & & & & $\boldsymbol{\alpha}=\mathbf{0 . 0 5}$ & $\boldsymbol{\alpha}=\mathbf{0 . 0 1}$ & \\
\hline 1 & $\mathrm{X} 3$ on X1 & 90 & $-0,0925$ & 0,0934 & 0,1087 & Normal \\
\hline 2 & $\mathrm{X} 3$ on X2 & 90 & $-0,1053$ & 0,0934 & 0,1087 & Normal \\
\hline 3 & Y on X1 & 90 & $-0,1000$ & 0,0934 & 0,1087 & Normal \\
\hline 4 & Y on X2 & 90 & $-0,1044$ & 0,0934 & 0,1087 & Normal \\
\hline 5 & Y on X3 & 90 & $-0,0857$ & 0,0934 & 0,1087 & Normal \\
\hline
\end{tabular}

\section{Source: Primary data processed}

\section{Homogeneity Test}

Another requirement for using path analysis is that the verifiable variance bound to the independent variable must be homogeneous. Homogeneity variance testing is done through SPSS and Excel using the Barlett test. A homogeneous variance if produced when $\chi^{2}$ arithmetic $<\chi 2$ tables. Thus overall the homogeneity test calculation results can be seen in the summary in the following table:

Table 1.6 Summary of Homogeneity Tests

\begin{tabular}{|c|c|c|c|c|c|}
\hline No & Estimated & $\mathbf{X}^{\mathbf{2}}$ & $\mathbf{d f}$ & $\mathbf{X}_{\mathbf{h}}$ & Decision \\
\hline 1 & $\mathrm{X} 3$ on X1 & 20,367 & 72 & 92,808 & Homogen \\
\hline 2 & $\mathrm{X} 3$ on X2 & 15,949 & 76 & 97,351 & Homogen \\
\hline 3 & Y on X1 & 26,596 & 72 & 92,808 & Homogen \\
\hline 4 & Y on X2 & 22,282 & 76 & 97,351 & Homogen \\
\hline 5 & Y on X3 & 16,894 & 74 & 95,081 & Homogen \\
\hline
\end{tabular}

\section{Source: Primary data processed}

\section{Test Path Analysis}

Path analysis is used to analyze the pattern of relationships between variables with the aim to determine the direct or indirect influence of a set of independent (exogenous) variables on the dependent variable (endogenous). From the data processing through the SPSS program the following results are obtained: 
Table 1.7 Results of Path Analysis

\begin{tabular}{|c|c|c|c|c|c|c|c|}
\hline Information & $\rho$ & $\mathbf{T}_{\text {count }}$ & Sig & $\mathbf{T}$ table & $\mathbf{R}^{2}$ & $F_{\text {count }}$ & Sig \\
\hline Sub-Structure 1 & & & & \multirow{3}{*}{1,663} & \multirow{3}{*}{0,699} & \multirow{3}{*}{$\begin{array}{c}100,88 \\
7\end{array}$} & \multirow{3}{*}{0,000} \\
\hline Religiosity & 0,535 & 7,879 &, 000 & & & & \\
\hline Knowledge Level & 0,428 & 6,300 &, 000 & & & & \\
\hline Sub-Structure 2 & & & & \multirow{4}{*}{1,663} & \multirow{4}{*}{0,838} & \multirow{4}{*}{$\begin{array}{c}148,72 \\
2\end{array}$} & \multirow{4}{*}{0,000} \\
\hline Religiosity & 0,444 & 6,785 & 0,000 & & & & \\
\hline Knowledge Level & 0,129 & 2,129 & 0,036 & & & & \\
\hline Taxpayer Awareness & 0,441 & 5,584 & 0,000 & & & & \\
\hline
\end{tabular}

Source: Primary data processed

Based on the results of the path analysis in Sub-Structure 1, the path coefficient of religiosity and the level of knowledge of taxpayer awareness is 0.535 , and 0.428 with the coefficient of reflection or the contribution of religiosity and the level of knowledge of taxpayer awareness is (Rsquare) $=0.669$ which means that $69.99 \%$ awareness of taxpayers can be explained by the path of religiosity and level of knowledge. The amount of residual coefficient $(\rho \times 3 \varepsilon 1=\sqrt{ } 1-0.699)=0.549$ or $54.9 \%$ is the influence of other variables beyond religiosity and the level of knowledge. While the path analysis results in Sub-Structure 2 obtained the path coefficient of religiosity, the level of taxpayer knowledge and awareness of taxpayer compliance by $0.444,0.129$ and 0.441 , with the coefficient of determination or contribution of religiosity, the level of knowledge and awareness of taxpayers against taxpayer compliance is (Rsquare) $=0.838$, which means that $83.8 \%$ of taxpayer compliance can be explained by religiosity, level of knowledge and awareness of taxpayers. The amount of residual coefficient ( $\rho y \varepsilon 2$ $=\sqrt{ } 1-0.838)=0.402$ or $40.2 \%$ is the influence of other variables beyond religiosity, the level of knowledge and awareness of taxpayers. The results of the path coefficients in sub-structure 1 and sub-structure 2 produce structural equations, as follows:

$\mathrm{X}_{3}=0,535 \mathrm{X}_{1}+0,428 \mathrm{X}_{2}+0,549 \varepsilon_{1}$ dan $\mathrm{R}_{\mathrm{x} 3 \times 2 \times 1}^{2}=0,669$

$\mathrm{Y}=0,444 \mathrm{X}_{1}+0,129 \mathrm{X}_{2}+0,441 \mathrm{X}_{3}+0,402 \varepsilon_{2}$ dan $\mathrm{R}_{\mathrm{y \times 3 \times 2 \times 1}}^{2}=0,838$

\section{Hypothesis testing}

After testing the model, then testing the hypothesis to determine the direct and indirect effects between variables. The hypothesis proposed will be concluded through the calculation of the path coefficient value and the significance of each path studied. The results of the decision on the proposed hypothesis are explained as follows: 1. Religiosity has a direct effect on the awareness of taxpayers

Based on the calculation results it can be seen that the value of the path coefficient $(\mathrm{px} 3 \times 1)$ of 0.535 with tcount $=$ 7.879 , at $\alpha=0.05$ obtained ttable $=1.663$. Because the value of $t=7.879$ is greater than $t$ table $=1.663$, the path coefficient is significant. The results showed that religiosity directly affected taxpayer awareness of $(0.535 \times 0.535$ $\mathrm{x} 100 \%=28.62 \%$. Thus Hal was accepted.

2. Knowledge Level Has a Direct Impact on Taxpayer Awareness

Based on the calculation results it can be seen that the value of the path coefficient $(\mathrm{px} 3 \times 2)$ of 0.428 with tcount $=$ 6.300 , at $\alpha=0.05$ obtained ttable $=1.663$. Because the value of $t=6.300$ is greater than $\mathrm{t}$ table $=1.663$, the path coefficient is significant. The results showed that the level of knowledge directly affected the taxpayer awareness of $(0.428 \times 0.428 \times 100 \%=18.32 \%$. Thus Ha2 was accepted.

3. Religiosity has a direct effect on the compliance of taxpayers

Based on the calculation results it can be seen that the value of the path coefficient (pyx1) of 0.444 with tcount $=$ 6.785 , at $\alpha=0.05$ obtained ttable $=1.663$. Because the value of $t=6.785$ is greater than $t$ table $=1.663$, the path coefficient is significant. The results showed that religiosity had a direct effect on tax compliance by $(0.444 \mathrm{x}$ $0.444 \times 100 \%=19.71 \%$. Thus Ha3 was accepted.

4. Knowledge Level Has a Direct Impact on Taxpayer Compliance

Based on the calculation results it can be seen that the value of the path coefficient (pyx2) of 0.129 with tcount $=$ 2.129 , at $\alpha=0.05$ obtained ttable $=1.663$. Because the value of $t=2.129$ is greater than $t$ table $=1.663$, the path coefficient is significant. The results showed that the level of knowledge had a direct effect on tax compliance by $(0.129 \times 0.129 \times 100 \%=1.66 \%$. Thus Ha4 was accepted.

5. Awareness of Taxpayers Directly Influence Taxpayer Compliance

Based on the calculation results it can be seen that the value of the path coefficient (pyx3) of 0.441 with tcount $=$ 5.584 , at $\alpha=0.05$ obtained ttable $=1.663$. Because the value of $t=5.584$ is greater than $t$ table $=1.663$, the path coefficient is significant. The results showed that taxpayer awareness had a direct effect on tax compliance by $(0.441 \times 0.441 \times 100 \%=19.45 \%$. Thus Ha5 was accepted.

\section{Mediation Factor Testing}

To test the significance of the indirect effect, it can be done by comparing the $Z$ value of the calculated ab coefficient with the Ztable value of 1.96. If the value of Zhitung is greater than the value of Ztable, it can be 
concluded that there is a mediating effect (Ghozali, 2013). The calculation of mediation factor testing will be explained as follows:

1. Effect of taxpayer awareness in mediating the relationship between religiosity and taxpayer compliance

Table 1.8 Results of Mediation Test with Sobel Test

\begin{tabular}{|l|r|r|r|r|}
\hline DIRECT AND TOTAL EFFECTS & \multicolumn{1}{c|}{ Sig (two) } \\
\hline & Coeff & se & 14,4751 & 0,0000 \\
\hline $\mathrm{b}(\mathrm{YX})$ & 0,7094 & 0,0490 & 10,6108 & 0,0000 \\
\hline $\mathrm{b}(\mathrm{MX})$ & 0,7599 & 0,0716 & 8,0159 & 0,0000 \\
\hline $\mathrm{b}(\mathrm{YM} . \mathrm{X})$ & 0,4461 & 0,0556 & 6,5641 & 0,0000 \\
\hline $\mathrm{b}($ YX.M) & 0,3705 & 0,0564 & $\mathrm{z}$ & Sig (two) \\
\hline INDIRECT EFFECT And SIGNIFICANCE USING NORMAL DISTRIBUTION & \multicolumn{2}{c|}{6,3779} & 0,0000 \\
\hline
\end{tabular}

Source: Primary data processed

Testing the significance of indirect effects with the Sobel test obtained values of $\mathrm{z}=6.3779$ and $\mathrm{p}=0.0000$. Because $z$-value in the absolute price $>1.96$ and the level of statistical significance $z$ ( $p$-value) $<0.05$, it means that there is a mediating influence of taxpayer awareness of the relationship between religiosity and taxpayer compliance.

2. The influence of taxpayer awareness in mediating the relationship between the level of knowledge with taxpayer compliance

Table 1.9 Mediation Test Results with the Sobel Test

\begin{tabular}{|l|r|r|r|r|}
\hline DIRECT AND TOTAL EFFECTS & \multicolumn{1}{c|}{ Sig (two) } \\
\hline & Coeff & \multicolumn{1}{c|}{ se } & 8,1854 & 0,0000 \\
\hline b(YX) & 0,6438 & 0,0787 & 9,0803 & 0,0000 \\
\hline b(MX) & 0,8171 & 0,0900 & 10,5867 & 0,0000 \\
\hline b(YM.X) & 0,6558 & 0,0619 & 1,4830 & 0,1417 \\
\hline b(YX.M) & 0,1079 & 0,0728 & z & Sig (two) \\
\hline INDIRECT EFFECT And SIGNIFICANCE USING NORMAL DISTRIBUTION & \multicolumn{2}{c|}{ se } & 0,8747 & 0,0000 \\
\hline
\end{tabular}

Source: Primary data processed

Testing the significance of indirect effects with the Sobel test obtained values of $z=6.8747$ and $p=0.0000$. Because $z$-value in absolute price $>1.96$ and level of statistical significance $z$ ( $p$-value) $<0.05$, it means that there is a mediating influence of taxpayer awareness on the relationship between knowledge level and taxpayer compliance.

\section{Discussion}

\section{Religiosity has a direct effect on the awareness of taxpayers}

Testing hypothesis 1 proves that religiosity has a direct effect on taxpayer awareness. This is in line with Theory of Planned Behavior, which is a theory that motivates taxpayers to fulfill their tax obligations. Furthermore, the level of religiosity of taxpayers is the level of taxpayers about the extent to which taxpayers believe in and believe in their respective religions so as to carry out their respective religious teachings. Each religion must teach a kindness. This can be seen from the attitude of taxpayers in completing their tax obligations. Taxpayers who have high religiosity means that taxpayers will carry out tax obligations. This is because taxpayers who understand well about religion will do good. This is what drives taxpayers to have a high awareness of the importance of the role of tax for the State. Taxpayers who are religiously obedient will realize how important tax is for the country's development. Here the taxpayer consciously and without coercion to comply with all tax obligations.

The results of this study are in line with research conducted by Andhika \& Dudi (2016), Benk, et al (2016), and Nanik \& Zaenal (2018), who concluded that taxpayers who have high religiosity will not commit crimes by embezzling tax because the taxpayer is aware that by embezzling taxes means committing a crime that is prohibited by religion.

\section{Knowledge Level Has a Direct Impact on Taxpayer Awareness}

Hypothesis testing 2 proves that the level of knowledge directly affects the awareness of taxpayers. This means that taxpayer awareness will be formed if taxpayers have high knowledge about taxation so that they will be more aware of fulfilling their obligations as a good citizen, namely paying taxes. Increased knowledge of taxation both formal and informal will have a positive impact on taxpayer awareness in paying taxes (Suryadi, 2006). Knowledge 
and understanding of taxation regulations is a process by which taxpayers know about taxation and apply that knowledge to fulfill their tax obligations. Research on this variable was conducted by Rahman (2012) and Defranis et.al, (2016) stating that tax knowledge influences taxpayer awareness.

\section{Religiosity has a direct effect on the compliance of taxpayers}

Hypothesis testing 3 proves that religiosity has a direct effect on taxpayer compliance. This is in line with the theory of behavior, namely Theory of Planned Behavior. This theory explains about how someone is able to behave, when someone has the intention and motivation. For taxpayers who have high religiosity, it means that taxpayers are able to differentiate between good behavior and bad behavior. In the case of taxation, a good taxpayer should comply with everything related to taxation regulations. Taxpayers assume that by complying with all tax regulations the same as obeying religious teachings. Because all religions in the world always teach about goodness. Taxpayers who understand well about religion will apply in compliance with tax regulations. With taxpayers paying tax means, taxpayers behave properly. By behaving properly means the taxpayer complies with all tax regulations.

The results of this study support research conducted by Andhika \& Dudi (2016), Benk, et al (2016), and Nanik \& Zaenal (2018) religiosity affect the compliance of taxpayers. But different from the research conducted by Stella (2014) shows that religiosity does not affect taxpayer compliance. This is because taxpayers have different views between religious affairs and business matters.

\section{Knowledge Level Has a Direct Impact on Taxpayer Compliance}

Testing hypothesis 4 proves that the level of knowledge directly influences taxpayer compliance. This is in accordance with the taxation system in Indonesia which adopts a self assessment system that requires taxpayers to have knowledge related to tax regulations. Because how is it possible that taxpayers can carry out their obligations if they do not have knowledge of regulations, how to calculate, calculate up to report taxes. By having adequate tax knowledge, taxpayers can know and easily carry out the obligations that must be done in terms of taxation. The higher level of knowledge possessed by taxpayers will increase taxpayer compliance because taxpayers already know the function of taxes and the importance of taxes in the country's development. Lack of tax knowledge possessed is the cause of the low compliance of taxpayers. Tax counseling and socialization can be done by tax officials to provide the latest information on changes in tax rules.

The results of this study support the research conducted by Viega \& Fidiana (2017); Siti, et al (2017); and Beny, et al (2018), show that there is a positive effect of tax knowledge on tax compliance.

\section{Awareness of Taxpayers Directly Influence Taxpayer Compliance}

Testing hypothesis 5 proves that taxpayer awareness has a direct effect on taxpayer compliance. The results of this study are in line with the Theory of Planned Behavior, where taxpayers who have realized the importance of taxes for the State will be motivated to pay taxes according to tax rules. The motivation and intention of the taxpayer comes from the conscience of the taxpayer himself. For taxpayers who realize that the function of paying taxes themselves can support the State Revenue and Expenditure Budget, taxpayers will pay taxes on time. In addition, according to Pasaribu and Christine (2016), awareness of taxpayers is growing because of the tax collection system that adopts the Self Assesmet System. This system gives taxpayers freedom to calculate, pay and report taxes. The freedom granted by the government to these taxpayers will have a good impact. Because taxpayers assume in fulfilling tax obligations there is no intervention from the government how much tax should be paid. This is what raises awareness for taxpayers. High awareness of taxpayers in meeting these tax obligations will have an impact on the fulfillment of tax obligations in accordance with tax regulations. In other words, taxpayers are aware that tax is an obligation, taxpayers will immediately pay taxes on time.

The results of this study are in line with research conducted by Nanik \& Zaenal (2018) showing that the higher the level of awareness possessed by taxpayers, the higher the level of compliance possessed by taxpayers. But in contrast to research conducted by Tahar \& Rachman (2014), Nugroho, et al (2016), and Suharyono (2019), which shows that taxpayer awareness cannot affect taxpayer compliance because taxpayers pay taxes simply because they are afraid to get a penalty fine not because of the awareness of taxpayers.

\section{Conclusions}

Based on the results of the analysis and discussion that has been carried out namely regarding, the following conclusions can be given: 1) Religiosity has a direct effect on taxpayer awareness; 2) The level of knowledge directly affects the awareness of taxpayers; 3) Religiosity directly influences taxpayer compliance; 4) The level of knowledge directly affects the compliance of taxpayers; and 5) Awareness of taxpayers directly affects the compliance of taxpayers.

\section{Limitation}

This research is inseparable from the shortcomings and limitations. Limitations in this study are as follows: 1). This study only uses an Individual Taxpayer as a sampel; and 2). Respondents' perceptions submitted in writing in the form of questionnaire instruments greatly affect the validity of the results of the questionnaire because they 
are not accompanied, so the possible answers given do not correspond to the actual size scale or do not correspond to the intent and purpose of the question.

\section{Suggestions}

As explained earlier that this study contains limitations. But the results of this study can at least motivate further research. By considering the existing limitations, it is expected that future research will improve the following factors: 1). Future studies need to further examine using other variables to further strengthen the effect of tax revenue performance; 2 ). The sample used in subsequent studies should be separated between individual taxpayers and corporate taxpayers; 3 ) The method used in subsequent studies uses a questionnaire that is added with open questions accompanied by when filling in, so that the answers given by respondents can be directed according to the purpose and purpose of the question, and use the interview method.

\section{BIBLIOGRAPHY}

Ajzen, Icek, 2002. Constructing a TPB Questionnaire: Conceptual and Methodological Considerations. September (Revised January, 2006).

Andhika Utama dan Dudi Wahyudi. 2012. Pengaruh Religiusitas terhadap Perilaku Kepatuhan Wajib Pajak Orang Pribadi di Provinsi DKI Jakarta. Jurnal Lingkar Widyaiswara, Edisi 3 No. 2, Apr - Jun 2016, p. $01-13$

Axel dan Mulyani. 2019. Pengaruh Tax Amnesty Terhadap Kepatuhan Wajib Pajak Dengan Pengetahuan Pepajakan sebagai Pemoderasi. Jurnal Akuntansi, Vol. 8, No. 1 Februari

Benk Serkan, Tamer Budak, Bahadýr Yüzba, and Raihana Mohdali. 2016. The Impact Of Religiosity On Tax Compliance Among Turkish Self-Employed Taxpayers. Religions. Vol. 7, No. 37

Beny Faturahman, Siti Nurlaela dan Endang Masitoh. 2018. Pengaruh Pengetahuan Perpajakan dan Tax Amnesty Terhadap Kepatuhan Perpajakan Wajib Pajak Orang Pribadi Pasca Tax Amnesty. Seminar Nasional dan Call for Paper: Manajemen, Akuntansi dan Perbankkan 2018

Defantris Hari Kurniati; Mochammad Djudi M; dan Muhammad Saifi. 2016. Pengaruh Pengetahuan Perpajakan dan Kualitas Pelayanan Terhadap Kesadaran Wajib Pajak Dalam Menyampaikan Surat Pemberitahuan (SPT) Tahunan (Studi pada Wajib Pajak Orang Pribadi yang Terdaftar di KPP Pratama Blitar). Jurnal Perpajakan (JEJAK). Vol. 9, No. 1

Dewi Fitriyani, Eko Prasetyo, Reni Yustien, Achmad Hizazi. 2014. Pengaruh Gender, Latar Belakang Pekerjaan, dan Tingkat Pendidikan Terhadap Kepatuhan Wajib Pajak. Jurnal InFestasi. Vol. 10, No. 2

Imam Ghozali. 2013. Aplikasi Analisis Multivariate Dengan Program IBM SPSS 22. Badan Penerbit Universitas Diponegoro, Semarang.

Isthi Wahyuning Tyas. 2013. Pengaruh Umur, Pendidikan, Penghasilan Bruto, dan Moral Terhadap Kepatuhan Pembayaran Pajak (Studi Empiris WPOP Usahawan pada Mall Ciputra). Jurnal TEKUN. Vol. IV, No. 02,

Mardiasmo. 2016. Perpajakan Edisi Terbaru 2016. Yogyakarta: ANDI.

Wana Mayasari, Zaitul, Resti Yulistia Muslim. 2015. Pengaruh Ketaatan Beragama Terhadap Moral Pajak. Ejurnal Universitas Bung Hatta. Vol 6, No 1.

Nanik Ermawati dan Zaenal Afifi. 2018. "Pengaruh Religiusitas Terhadap Kepatuhan Wajib Pajak dengan Kesadaran Wajib Pajak sebagai Variabel Intervening. Jurnal Akuntansi Indonesia. Vol. 7, No. 2, Hal. 49 $-62$

Nugroho Aditya, Rita Andini, dan Kharis Raharjo. 2016. Pengaruh Kesadaran Wajib Pajak Dan Pengetahuan Perpajakan Wajib Pajak Terhadap Kepatuhan Wajib Pajak Dalam Membayar Pajak Penghasilan (Studi Kasus Pada KPP Semarang Candi). Journal Of Accounting. Vol. 2 No. 2 Maret

Nurulita Rahayu. 2017. Pengaruh Pengetahuan Perpajakan, Ketegasan Sanksi Pajak, dan Tax Amnesty terhadap Kepatuhan Wajib Pajak. Akuntansi Dewantata. Vol. 1, No. 1.

Rahman Adi Nugroho. 2012. Faktor Faktor yang Mempengaruhi Kemauan Untuk Membayar Pajak Dengan Kesadaran Membayar Pajak Sebagai Variabel Intervening. Jurnal S1 Akuntansi Fakultas Ekonomika dan Bisnis. Universitas Diponegoro. Vol. 1, No. 2.

Siti Nurlaela, Bambang Mursito, Solichul Hadi, dan Kartika Hendra Titisari. 2017. Effect Of Understanding, Knowledge and Tax Amnesty to Pay Complience With Individual Parliament Regionalin Indonesia. Account and Financial Management Journal ISSN: 2456-3374

Stella Rahmawaty. 2014. Pengaruh Pengetahuan Modernisasi Strategi Direktoral Jenderal Pajak, Sanksi Perpajakan dan Religiusitas yang Dipersepsikan Terhadap Kepatuhan Perpajakan. Jurnal Ilmiah Mahasiswa Fakultas Ekonomi dan Bisnis Universitas Brawijaya. Vol. 3, No 1.

Suharyono. 2019. Pengaruh Kesadaran Wajib Pajak dan Pengetahuan Perpajakan Terhadap Kepatuhan Wajib Pajak dalam Membayar Pajak Bumi dan Bangunan di Kabupaten Bengkalis. Jurnal Inovasi Bisnis. Vol. 7, No. 1 
Tahar Frizal, dan Arnain Kartika Rachman. 2014. Pengaruh Faktor Internal Dan Faktor Eksternal Terhadap Kepatuhan Wajib Pajak. Jurnal Akuntansi \& Investasi. Vol. 15 No.1 Januari 2

Undang-undang Nomor 28 Tahun 2007 tentang Ketentuan Umum Perpajakan.

Viega Ayu Permata Sari, dan Fidiana. 2017. Pengaruh Tax Amnesty, Pengetahuan Perpajakan, dan Pelayanan Fiskus Terhadap Kepatuhan Wajib Pajak. Jurnal Ilmu dan Riset Akuntansi. Vol. 6, No. 2

Waluyo, 2011. Perpajakan Indonesia, Edisi 10 buku 1. Jakarta : Salemba Empat 